\title{
Effects of intravenous triacylglycerol emulsions on lymphocyte responses to mitogens in fasted dairy cows undergoing intense lipomobilization
}

\author{
Nicola Lacetera ${ }^{1}$, Daniela Scalia ${ }^{1}$, Dough G Mashek $^{2}$, Umberto Bernabucci ${ }^{1}$ \\ and Ric R Grummer ${ }^{2}$ \\ ${ }^{1}$ Dipartimento di Produzioni Animali, Università della Tuscia, Italy \\ ${ }^{2}$ Department of Dairy Science, University of Wisconsin-Madison, USA
}

Received 5 July 2006 and accepted for publication 23 January 2007

\begin{abstract}
The objective of the study was to assess the effects of intravenous infusion of triacylglycerol (TAG) emulsions derived from different lipid sources on responses to mitogens of peripheral blood mononuclear cells (PBMC) isolated from fasted dairy cows. Six multiparous, nonpregnant, non-lactating Holstein cows were used in a replicated $3 \times 3$ Latin Square design. For $4 \mathrm{~d}$, cows were fasted and infused intravenously with a 20\% TAG emulsions derived from tallow (TA), linseed oil (LO) or fish oil (FO). Fasting was employed to induce energy deficit and lipid mobilization. Emulsions were administered for 20 to 30 min every $4 \mathrm{~h}$ throughout the $4 \mathrm{~d}$ fast at a rate of $0.54 \mathrm{~g}$ TAG $/ \mathrm{kg}$ BW/d. Blood samples were taken before the first infusion, and then every $24 \mathrm{~h}$ during the fast. Blood was utilized to assess DNA synthesis, IgM and interferon-gamma (IFN- $\gamma$ ) secretion by PBMC stimulated with mitogens. In TA infused cows there was a decline of PBMC ability to respond to mitogens, which was significant $48 \mathrm{~h}$ after initiation of the infusion period for DNA synthesis and IFN- $\gamma$ secretion. In LO or FO infused cows, PBMC responses to mitogens were not altered during the infusion period, and in some cases PBMC responses to mitogen was improved at 72 and $96 \mathrm{~h}$ after initiation of treatments. Effects of TAG infusion on PBMC responses to mitogens depended on the lipid source suggesting that LO or FO can attenuate the negative effects of fasting on immune functions.
\end{abstract}

Keywords: Triacylglycerol emulsions, dairy cows, lymphocytes.

Several in vitro and in vivo studies carried out in humans and laboratory animals have demonstrated that fatty acids (FA) can modulate immune functions (de Pablo \& de Cienfuegos, 2000; Calder et al. 2002).

We have previously documented that high plasma nonesterified fatty acids (NEFA) or high concentrations of the same FA (palmitic, palmitoleic, stearic, oleic, and linoleic acid) in the culture media are associated with impairment of lymphocyte response to mitogens both in sheep (Lacetera et al. 2001, 2002) and cows (Lacetera et al. $2004,2005)$. On the basis of these findings, the increase of plasma NEFA consequent to lipomobilization is now assumed to represent one of the possible mechanisms to explain the immunodepression taking place in early lactating dairy cows suffering from negative energy balance

*For correspondence; e-mail : nicgio@unitus.it
(Kehrli et al. 2006). Furthermore, a recent in vitro study indicated that bovine peripheral blood mononuclear cells (PBMC) may be functionally influenced by the presence of polyunsaturated fatty acids (PUFA) in their environment (Thanasak et al. 2005).

Little is known about the immunomodulatory properties of exogenous FA when administered to ruminants. However, Lessard and co-workers reported that a series of PBMC functions in transition dairy cows is modulated by composition of $\mathrm{FA}$ in the diet, that such modulation may depend on n- 6 to $n-3$ FA ratio, and that effects may vary according to the length of diet administration (Lessard et al. 2003, 2004).

The present study aimed to assess whether changes in fatty acid profile of blood lipids due to intravenous infusion of triacylglycerol (TAG) emulsions derived from different lipid sources affect PBMC responses to mitogens in fasted dairy cows. 
Table 1. Fatty acid composition of triacylglycerol emulsions

$\begin{array}{lccr}\text { Fatty acid } & \text { Tallow } & \begin{array}{c}\text { Linseed oil } \\ \end{array} & \text { Fish oil } \\ 14: 0 & 3 \cdot 11 & 0 \cdot 04 & 7 \cdot 40 \\ 16: 0 & 25 \cdot 98 & 6 \cdot 00 & 20 \cdot 51 \\ 16: 1 & 3 \cdot 17 & 0 \cdot 08 & 10 \cdot 02 \\ 17: 0 & 1 \cdot 30 & 0 \cdot 04 & 0 \cdot 65 \\ 18: 0 & 17 \cdot 87 & 4 \cdot 13 & 4 \cdot 15 \\ 18: 1 & 43 \cdot 09 & 20 \cdot 96 & 15 \cdot 21 \\ 18: 2 & 2 \cdot 84 & 16 \cdot 81 & 3 \cdot 11 \\ 18: 3 & 0 \cdot 43 & 51 \cdot 13 & 1 \cdot 70 \\ 20: 1 & 0 \cdot 22 & 0 \cdot 24 & 1 \cdot 75 \\ 20: 4 & 0 \cdot 20 & 0 \cdot 12 & 1 \cdot 03 \\ 20: 5 & N D^{1} & 0 \cdot 12 & 13 \cdot 55 \\ 22: 6 & N D & 0 \cdot 11 & 18 \cdot 46 \\ \text { Other } & 1 \cdot 79 & 0 \cdot 22 & 2 \cdot 46\end{array}$

${ }^{1} \mathrm{ND}=$ Not detected

\section{Materials and Methods}

\section{Reagents}

Reagents, TAG emulsion preparation, animals, and treatments for the study were described elsewhere (Mashek et al. 2005). A brief description of each follows.

Tallow (TA; HRR Enterprises Inc., Chicago, IL), linseed oil (LO; Archer Daniels Midland, Decatur, IL), and menhaden fish oil (FO; Omega Protein, Inc., Hammond, LA) were donated. Lecithin (60\% purity) was purchased from ICN Chemicals (Irvine, CA).

\section{Emulsion Preparation}

Each of the three lipid sources contained the same amount of ethoxyquin to prevent peroxidation. In separate containers, $200 \mathrm{~g}$ lipid source or $765 \mathrm{ml}$ water were heated to approximately $70{ }^{\circ} \mathrm{C}$. Lecithin ( $12 \mathrm{~g}$ ) was added to the water and the mixture was homogenized in a blender. Glycerol (50 g) was then added to the heated lipid followed by the lecithin and water mixture. A coarse emulsion was prepared by homogenizing the mixture in the blender. Subsequently, the emulsion was passed through an homogenizer. The recipient flask was placed in cold water during the homogenization process to cool the emulsion. After adjusting the $\mathrm{pH}$ to 8.3 with $1 \mathrm{~m}-\mathrm{NaOH}$, emulsions were autoclaved. The flasks were then cooled in water and the contents were aseptically transferred to sterile bottles and stored at $4{ }^{\circ} \mathrm{C}$ with the exception of emulsions containing TA. These were never allowed to cool below room temperature and were stored at $37^{\circ} \mathrm{C}$ to prevent creaming.

Fatty acid composition of TAG emulsions is shown in Table 1. In the TA emulsion, the most common FA in ruminants, C16:0, C18:0, and C18: 1 accounted for 86.9\% of total FA, whereas PUFA were not detectable (C20:5 and $\mathrm{C} 22: 6)$ or represented at very low concentration
(C18:2, C18:3, C20:1, and C20:4). Compared with TA, in the LO and FO emulsions the proportion of PUFA was much greater and accounted for 68.5 and $39.6 \%$ of total FA, respectively.

\section{Animals and Treatments}

Six multiparous, non-pregnant, non-lactating Holstein cows were randomly assigned to treatments in a replicated $3 \times 3$ Latin Square design. The average age of cows was $4 \cdot 7 \mathrm{yr}$, and average BW and BCS were $735 \mathrm{~kg}$ and $3 \cdot 6$, respectively. Treatments consisted of fasting and an intermittent intravenous infusion of a $20 \%$ TAG emulsion derived from TA, LO, or FO. During each of the three infusion periods, 2 cows were infused with TA, 2 with LO, and 2 with FO emulsions. Therefore, by the end of the experiment each cow had been infused with each of the three emulsions. During the infusion periods, cows were fasted to induce energy deficit and lipid mobilization. TA was chosen as a control treatment because it represents the FA composition normally found in ruminants, and its use ensured isocaloric conditions across treatments. The emulsions were given via drip infusion over a 20 to $30 \mathrm{~min}$ period every $4 \mathrm{~h}$ at a rate of $0.54 \mathrm{~g}$ TAG/ $\mathrm{kg}$ BW daily for $4 \mathrm{~d}$. Between the three infusion periods, cows were given $24 \mathrm{~d}$ during which they were fed a basal diet consisting of alfalfa grass hay and a supplement containing corn grain, soy hulls, and minerals and vitamins to meet or exceed NRC recommendations (NRC, 2001). During infusion periods, cows were given approximately $100 \mathrm{~g}$ of the supplement with high concentrations of minerals and vitamins to meet their daily requirements. Cows were housed on a bedded pack between infusions and in tie stalls during the infusion period. Cows were allowed to exercise in an open lot for $2 \mathrm{~h} / \mathrm{d}$ during the infusion period and were offered water ad libitum. The University of Wisconsin Animal Care and Use Committee approved all animal related procedures.

\section{Sampling and Analysis}

Twenty $\mathrm{ml}$ blood were sampled every $24 \mathrm{~h}$ throughout the $4 \mathrm{~d}$ infusion/fast period and placed in Vacutainer tubes containing Na-heparin. Ten $\mathrm{ml}$ blood were centrifuged and plasma samples were analysed for NEFA (NEFA-C kit; Wako Fine Chemical Industries USA, Inc., Dallas TX); the remaining $10 \mathrm{ml}$ were utilized to assess DNA synthesis, IgM and interferon-gamma (IFN- $\gamma$ ) secretion in PBMC stimulated with mitogens.

The DNA synthesis was evaluated as previously described (Lacetera et al. 2001). After isolation, PBMC were resuspended at a concentration of $1 \times 10^{6}$ cells/ml RPMI1640 enriched culture medium. Triplicate cultures were assayed, by using 96-well tissue-culture plates. Each well contained $1 \times 10^{5}$ mononuclear cells in $100 \mu$ l enriched culture medium. Control wells contained $100 \mu \mathrm{l}$ PBMC suspension without mitogens. Additional control wells 
were used that contained $100 \mu$ l enriched culture medium without cells or $100 \mu \mathrm{l}$ PBMC suspension without the pyrimidine analogue 5-bromo-2'-deoxyuridine (BrdU). An optimal concentration of phytohemagglutinin (PHA, $2.5 \mu \mathrm{g} / \mathrm{ml}$ ), pokeweed mitogen (PWM, $1 \mu \mathrm{g} / \mathrm{ml}$ ) or concanavalin A (ConA, 2.5 $\mu \mathrm{g} / \mathrm{ml}$; Sigma, Milan, Italy) was added to plates. Plates were incubated in an atmosphere of $95 \%$ air and $5 \% \mathrm{CO}_{2}$ for $48 \mathrm{~h}$ at $39{ }^{\circ} \mathrm{C}$. Afterwards, $100 \mu \mathrm{M}-\mathrm{BrdU}$ in $10 \mu \mathrm{l} \mathrm{RPMI}-1640$ were added to each well, and plates were incubated for an additional $18 \mathrm{~h}$. The DNA synthesis was quantified by an ELISA assay. The assay was performed with a commercial kit (APB, Milan, Italy) that is based on measurement of BrdU incorporated during DNA synthesis in proliferating cells. Values for DNA synthesis were expressed as the optical density (OD) of test wells minus the OD of control wells that did not contain BrdU.

Secretion of IgM was established by growing PWMstimulated cells $\left(1 \times 10^{6}\right.$ cells/well $)$ under the same conditions described above. Concentration of PWM was $0 \cdot 2 \mu \mathrm{g} / \mathrm{ml}$. Cells were cultured in duplicate for $12 \mathrm{~d}$ in 24-well tissue-culture plates. At the end of the incubation supernatants were collected and stored at $-20{ }^{\circ} \mathrm{C}$ until analysed. The IgM released in culture medium were quantified by a single dilution capture ELISA system (Graham et al. 1998a, b). Plates were coated with rabbit affinity purified antibody against bovine IgM which were detected by use of a phosphatase-conjugated sheep antibovine IgM- $\mu$ chain specific polyclonal antibody (Lacetera et al. 2004). Antibodies were purchased from Bethyl Laboratories (Montgomery, TX). Supernatant samples were tested in duplicate at dilution of $1 / 24$ on plates coated with diluted capture antibody (1/1500). The mean OD of each supernatant at $1 / 24$ was calculated and the corrected OD (COD) obtained by subtracting the mean OD of the control wells. Purified bovine IgM (VMRD, Pullman, WA) at concentration of $20 \mathrm{ng} / 100 \mu \mathrm{l}$ (volume added to wells) were used as positive reference sample. Differential IgM secretions were evaluated by calculating the ratio between COD of each sample and COD of positive reference sample.

Secretion of IFN- $\gamma$ was established by growing ConAstimulated cells $\left(1 \times 10^{6}\right.$ cells/well $)$ under the same conditions described above. Cells were cultured in duplicate for $72 \mathrm{~h}$ in 24-well tissue-culture plates. At the end of incubation supernatants were collected and stored at $-20{ }^{\circ} \mathrm{C}$ until analysed. The IFN- $\gamma$ released in culture medium was quantified by a single dilution capture ELISA system, which was carried out by use of a commercial kit (CSL, Victoria, Australia). The IFN- $\gamma$ concentration $(\mathrm{ng} / \mathrm{ml}$ ) was established by using the same method utilized for IgM quantification. Supernatant samples were tested in duplicate at dilution of $1 / 8$ on plates coated with the capture antibody. The mean OD of each supernatant at $1 / 8$ was calculated and the COD obtained by subtracting the mean OD of the control wells. In this case, bovine recombinant IFN- $\gamma$, which was kindly provided by Dr. Stephen Jones
(CSL, Victoria, Australia) at concentration of $62.5 \mathrm{pg} / 100 \mu \mathrm{l}$ (volume added to wells) was used as positive reference sample. Differential IFN- $\gamma$ secretions were evaluated by calculating the ratio between COD of each sample and COD of positive reference sample.

\section{Statistical Analysis}

Data were analysed using the Mixed procedure of SAS (SAS, 2001). For repeated measurements, the model included a covariate, fixed effects of period, treatment, and time, random effects of cow (square), 2-way interactions of fixed effects, and the residual error. The covariate and interactions were removed if they were not significant $(P>0 \cdot 10)$ in the model. If factors included in the model were significant $(P<0 \cdot 05)$, the PDIFF procedure was used to determine differences. Significance was declared at $P<0 \cdot 05$.

\section{Results}

The infusion of the three TAG emulsions exerted different effects on DNA synthesis of PBMC (Fig. 1). In PBMC isolated from cows infused with TA, a decrease $(P<0 \cdot 01)$ of DNA synthesis was observed $48 \mathrm{~h}$ after initiation of the infusion. Afterwards, values gradually increased, and after $96 \mathrm{~h}$ they did not differ from initial values. Basically, in cows infused with LO or FO DNA synthesis of PBMC did not change during the infusion period. However, in cows infused with LO an increase $(P<0 \cdot 01)$ of DNA synthesis was observed in PBMC stimulated with PHA at the end of the infusion period $(96 \mathrm{~h})$. Significant differences were also detected among treatments (LO or FO vs. TA). Compared with TA treatment, $48 \mathrm{~h}$ after the beginning of the infusions, DNA synthesis was higher in PBMC isolated from cows infused with $\mathrm{LO}$ or FO and stimulated with all 3 mitogens; $72 \mathrm{~h}$ after initiation of the infusions DNA synthesis was also higher in LO and FO cows, but only in PBMC stimulated with PHA and PWM; at the end of the infusion period ( $96 \mathrm{~h}$ ) superiority of LO and FO cows was detected only for PBMC stimulated with PWM.

Infusion of TA did not affect IgM secretion (Fig. 2). Conversely, infusions of LO or FO were responsible for an overall increase of IgM secretion, which became significant $(P<0 \cdot 01) 72 \mathrm{~h}$ after the first infusion. Furthermore, $72 \mathrm{~h}$ after initiation of the infusions, IgM secreted from PBMC isolated from cows infused with FO and LO were higher $(P<0 \cdot 01)$ than those recorded in their TA counterparts.

In PBMC isolated from cows infused with $\mathrm{TA}$, a decrease $(P<0 \cdot 01)$ of IFN- $\gamma$ synthesis was observed $48 \mathrm{~h}$ after initiation of the infusion (Fig. 3). At that time, values of IFN- $\gamma$ in cows infused with TA were lower $(P<0.05)$ than those recorded in their FO or LO counterparts. Infusion of FO or LO did not modify the ability of PBMC to secrete IFN- $\gamma$ over the fasting and infusion period. 



Fig. 1. Effects of triacylglycerol emulsions derived from tallow $(\bigcirc-\ldots)$, linseed oil $(-\ldots)$ and fish oil $(\triangle--\triangle)$ on DNA synthesis (optical density, $\mathrm{OD}$ ) in peripheral blood mononuclear cells stimulated with phytohemagglutinin (A), concanavalin A (B), and pokeweed mitogen (C). Significant effects in the model: treatment $(P<0 \cdot 01)$, treatment $\times$ time $(P<0 \cdot 01)$. Values with different letters indicate significant differences $(P<0 \cdot 01)$ within treatment. Significant contrasts $(*)$ : fish and linseed oil vs. tallow $(P<0 \cdot 01)$. Data represent least squares means and standard error of the mean.

\section{Discussion}

Several authors indicated that conditions of energy deficit and intense lipid mobilization in dairy cows are associated with impairment of leukocyte functions (Szuster-Ciesielska et al. 1995; Kaneene et al. 1997; Hoeben et al. 2000). Furthermore, studies undertaken in periparturient dairy sheep (Lacetera et al. 2001) or cows (Lacetera et al. 2005) demonstrated that the intensity of lipid mobilization, as estimated by measuring concentration of plasma NEFA, is positively related with the degree of immune deficiency. Results of the current study reported previously (Mashek et al. 2005) indicated that during the fasting and infusion periods all cows showed a significant increase of plasma NEFA, and that the only significant difference among treatments was a lower concentration of plasma NEFA in cows infused with LO compared with TA. This would indicate that, in our conditions, differences among treatments in PBMC response to mitogens can be only partially explained by a different intensity of the lipid mobilization or NEFA clearance from blood consequent to fasting.

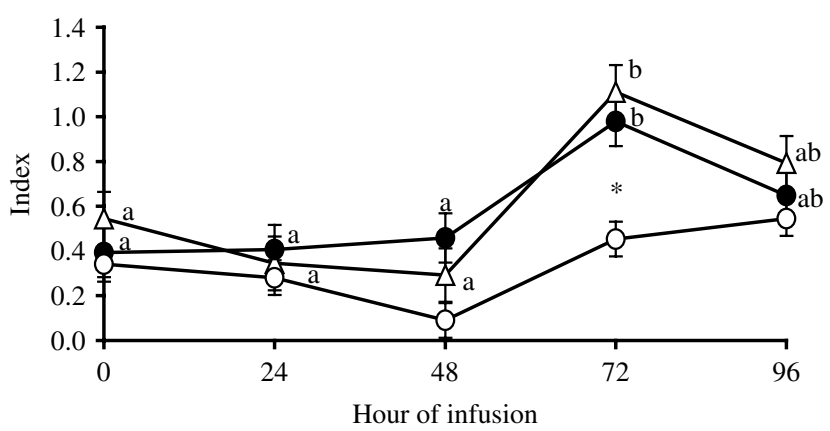

Fig. 2. Effects of triacylglycerol emulsions derived from tallow $(\bigcirc--\bigcirc)$, linseed oil $\left(-\mathbf{-}_{-}\right)$and fish oil $(\triangle--\triangle)$ on $\lg M$ secretion in peripheral blood mononuclear cells stimulated with pokeweed mitogen. Index on the $y$ axis is the ratio between the optical density (OD) of the sample and OD of a positive reference sample. Significant effects in the model: treatment $(P<0 \cdot 01)$, treatment $\times$ time $(P<0 \cdot 01)$. Values with different letters indicate significant differences $(P<0 \cdot 01)$ within treatment. Significant contrasts $\left({ }^{*}\right)$ : fish and linseed oil vs. tallow $(P<0 \cdot 01)$. Data represent least squares means and standard error of the mean.

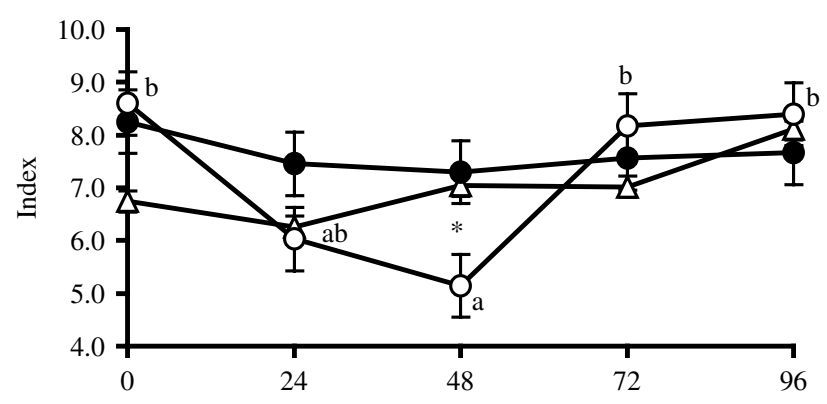

Fig. 3. Effects of triacylglycerol emulsions derived from tallow $(\bigcirc--\bigcirc)$, linseed oil $\left(-\mathbf{O}^{-}\right)$and fish oil $(\triangle--\triangle)$ on IFN- $\gamma$ secretion in peripheral blood mononuclear cells stimulated with concanavalin A. Index on the $y$ axis is the ratio between the optical density (OD) of the sample and OD of a positive reference sample. Significant effects in the model: treatment $(P<0 \cdot 01)$, treatment $\times$ time $(P<0 \cdot 01)$. Values with different letters indicate significant differences $(P<0 \cdot 01)$ within treatment. Significant contrasts $(*)$ : fish and linseed oil vs. tallow $(P<0 \cdot 01)$. Data represent least squares means and standard error of the mean.

Further results from the current study also reported elsewhere (Mashek et al. 2005) indicated that treatments affected FA composition of plasma. Infusion of TA increased the proportion of C16:0 compared with the LO and FO emulsions, whereas infusion of LO increased C18:3 compared with TA or FO emulsions. The C20:5 and C22: 6 FA were not detected in plasma NEFA of cows receiving TA or $\mathrm{LO}$, but represented 2.62 and $1.99 \%$ of plasma NEFA of cows receiving FO. Furthermore, treatments also affected plasma n-6 to n-3 FA ratio, in that TA infused cows showed a higher $n-6$ to $n-3$ FA ratio $(4 \cdot 04)$ 
compared with LO $(1 \cdot 26)$ or FO $(1 \cdot 14)$ infused cows. These observations suggest that the different effects of treatments on PBMC responses to mitogens stimulation may have been at least partially mediated by the influence of TAG emulsion infusions on plasma FA composition. In particular, previous studies carried out in sheep and cows (Lacetera et al. 2002, unpublished) pointed out strong inhibitory effects of C16:0 on PBMC functions, whereas Lessard and co-workers (Lessard et al. 2004) found that dietary PUFA can attenuate some of the periparturient alterations of lymphocyte functions in dairy cows. In detail, these authors reported that dietary administration of whole flaxseed in periparturient dairy cows reduced blood n-6 to n-3 FA ratio, and was associated with preservation of proliferative response in mitogen-stimulated blood lymphocytes. Studies carried out in other species demonstrated that changes of biophysical and functional properties of cellular membranes (Anel et al. 1993) due to FA administration may explain changes of lymphocyte functions. In our study we did not determine FA compositions of PBMC, so that we can not attribute the effects of treatments to changes of PBMC composition in terms of FA. However, according to a recent study carried out in humans (Skeaff et al. 2006), we can hypothesize that $4 \mathrm{~d}$ fasting/infusion period was associated also with changes in FA composition of PBMC membranes. Skeaff et al. (2006) indicated that few days of dietary administration of FA are sufficient to induce changes both in plasma and blood cells FA composition, and that dietary-induced change in plasma FA is similar to that occurring in blood cells. Authors concluded that their results provide convincing, albeit indirect evidence that the exchange of FA from plasma to blood cells is a major determinant of their membrane FA composition. Furthermore, Zurier et al. (1999) demonstrated that incorporation of FA from lymphocytes is a very rapid process, and that a few min incubation of lymphocytes with culture media enriched with FA is sufficient to significantly change FA composition of cells. However, with regard to our study, the hypothesis that effects of treatments were due to changes in FA composition of PBMC would not explain why most of those effects were not evident at the end of fasting/infusion periods. In particular, it would not explain why in TA cows PBMC functions were strongly inhibited during the first $48 \mathrm{~h}$ and above all why such inhibition did not last until the end of observation period. Previous studies demonstrated that modulation of cell death via apoptosis or necrosis (de Pablo et al. 1999) may also represent a mechanism through which FA modulate lymphocyte functions. In our study, as already indicated, most of the differences among treatments were detected between 48 and $72 \mathrm{~h}$, and were basically due to a significant decrease of lymphocyte functions in cows infused with TA. Classical studies (Kerndt et al. 1982; Lomax \& Baird, 1983) demonstrated that following $48 \mathrm{~h}$ fasting a metabolic adaptation occurs in the body, so that after consuming glucose derived from liver glycogen, cells start to utilize other fuels (basically NEFA and ketones) which become largely available after that time. Results of our study published elsewhere (Mashek et al. 2005) demonstrated that in our conditions the maximum plasma concentration of NEFA and ketones were reached after 48-72 $\mathrm{h}$ from beginning of fasting/infusion. Interestingly, literature data (Hunnicutt et al. 1994; Usui et al. 1997; Lee et al. 2006) indicate that saturated FA (more abundant in plasma of TA cows) are responsible for insulin resistance, which in our conditions would be consistent with higher plasma glucose observed in TA cows (Mashek et al. 2005). In our conditions such effects of saturated FA might have caused a reduced ability of immune cells from TA cows to utilize glucose when this represented the main energy source (first 48-72 $\mathrm{h}$ fasting). In this regard, it must also be noticed that reduced uptake of glucose from immune cells may be responsible for hyporesponsiveness (Frauwirth \& Thompson, 2004) or increased cell death (Alves et al. 2006; Jacobs \& Rathmell, 2006). Therefore, we can hypothesize that the reduced ability of PBMC from TA cows to respond to lectins during the first $48-72 \mathrm{~h}$ fasting might be due to the fact that when isolated from blood, PBMC were in a distressed state due to a reduced glucose uptake. On the other hand, other studies demonstrated that fasting per se is associated with an increase of cell death by apoptosis (Pires et al. 2006), and that saturated FA increase predisposition of lymphocytes to such event (Carratelli et al. 1999). After 48-72 h fasting, increased availability of NEFA and ketones may have restored the ability of immune cells from TA cows to respond to lectins stimulation.

In conclusion, under conditions of energy deficit and lipid mobilization due to fasting, administration of LO or FO would permit to attenuate alteration of lymphocyte responses to mitogens. With regard to practical situations, our findings may be of particular interest for conditions of transient anorexia, which may occur with a certain frequency during transition period (Bertoni et al. 2004) or disease states (Kulcsar et al. 2005) and that are likely to predispose cows to further health problems. Finally, current results support conclusions from previous studies (Lessard et al. 2004) illustrating the potential importance of dietary lipids, and in particular of unsaturated FA, on modulating immune functions during periods that are known to be critical for the immune response.

The research was sponsored by MIUR (PRIN 2005), and Università della Tuscia. The authors recognize also Bioproducts, Inc., Pioneer Hi-Bred International Inc., Degussa Corp., ADM Alliance Nutrition Inc., Kemin Americas, Church and Dwight Co., Inc., Land O'Lakes Inc., Diamond V Mills., and Zinpro Corp., for partial financial support.

\section{References}

Alves NL, Derks IA, Berk E, Spijker R, van Lier RA \& Eldering E 2006 The Noxa/Mcl-1 axis regulates susceptibility to apoptosis under glucose limitation in dividing T cells. Immunity 24 703-716 
Anel A, Richieri GV \& Kleinfeld AM 1993 Membrane partition of fatty acids and inhibition of $\mathrm{T}$ cell function. Biochemistry $\mathbf{3 2}$ 530-536

Bertoni G, Trevisi E \& Piccioli-Cappelli F 2004 Effects of acetyl-salicylate used in post-calving of dairy cows. Veterinary Research Communications 28 217-219

Calder PC, Yaqoob P, Thies F, Wallace FA \& Miles EA 2002 Fatty acids and lymphocyte functions. British Journal of Nutrition 87 31-48

Carratelli CR, Nuzzo I, Vitiello T, Galdiero E \& Galdiero F 1999 The effect of dietary lipid manipulation on murine splenic lymphocytes apoptosis and heat shock protein over expression. FEMS Immunology and Medical Microbiology 24 19-25

de Pablo MA, Susin SA, Jacotot E, Larochette N, Costantini P, Ravagnan L, Zamzani N \& Kroemer G 1999 Palmitate induces apoptosis via a direct effect on mitochondria. Apoptosis 4 81-87

de Pablo MA \& de Cienfuegos A 2000 Modulatory effects of dietary lipids on immune system functions. Immunology and Cell Biology 78 31-39

Frauwirth KA \& Thompson CB 2004 Regulation of T lymphocyte metabolism. Journal of Immunology 172 4661-4665

Graham DA, Mawhinney KA, Adair BM \& Merza M 1998a Testing of bovine sera by ELISA for IgG, IgM and IgA rheumatoid factors. Veterinary Immunology and Immunopathology 61 239-250

Graham DA, McShane J, Mawhinney KA, McLaren IE, Adair BM \& Merza M 1998b Evaluation of a single dilution ELISA system for detection of seroconversion to bovine viral diarrhoea virus, bovine respiratory syncytial virus, parainfluenza-3 virus, and infectious bovine rhinotracheitis virus: comparison with testing by virus neutralization and hemagglutination inhibition. Journal of Veterinary Diagnostic Investigation 10 43-48

Hoeben D, Monfardini E, Opsomer G, Burvenich C, Dosogne H, De Kruif A \& Beckers JF 2000 Chemiluminescence of bovine polymorphonuclear leucocytes during the periparturient period and relation with metabolic markers and bovine pregnancy-associated glycoprotein. Journal of Dairy Science 67 249-259

Hunnicutt JW, Hardy RW, Williford J \& McDonald JM 1994 Saturated fatty acid-induced insulin resistance in rat adipocytes. Diabetes $\mathbf{4 3}$ 540-545

Jacobs SR \& Rathmell JC 2006 Lymphocyte selection by starvation: glucose metabolism and cell death. Trends in Immunology 27 4-7

Kaneene JB, Miller RA, Herdt TH \& Gardiner JC 1997 The association of serum nonesterified fatty acids and cholesterol, management and feeding practices with peripartum disease in dairy cows. Preventive Veterinary Medicine 31 59-72

Kehrli ME, Neill JD, Burvenich C, Goff JP, Lippolis JD, Reinhardt TA \& Nonnecke BJ 2006 Energy and protein effects on the immune system. In Ruminant physiology. Digestion, metabolism and impact of nutrition on gene expression, immunology and stress, pp. 455-471 (Eds K Sejrsen, T Hvelplund \& MO Nielsen). Wageningen, Wageningen Academic Publishers

Kerndt PR, Naughton JL, Driscoll CE \& Loxterkamp DA 1982 Fasting: the history, pathophysiology and complications. The Western Journal of Medicine 137 379-399

Kulcsár M, Jánosi S, Lehtolainen T, Kátai L, Delavaud C, Balogh $O$, Chilliard Y, Pyörälä S, Rudas P \& Huszenicza G 2005 Feedingunrelated factors influencing the plasma leptin level in ruminants. Domestic Animal Endocrinology 29 214-226
Lacetera N, Bernabucci U, Ronchi B \& Nardone A 2001 Effects of subclinical pregnancy toxemia on immune responses in sheep. American Journal of Veterinary Research 62 1020-1024

Lacetera N, Franci O, Scalia D, Bernabucci U, Ronchi B \& Nardone A 2002 Effects on functions of ovine blood mononuclear cells for each of several fatty acids at concentrations found in plasma of healthy and ketotic ewes. American Journal of Veterinary Research 63 958-962

Lacetera N, Scalia D, Franci O, Bernabucci U, Ronchi B \& Nardone A 2004 Effects of nonesterified fatty acids on lymphocyte function in dairy heifers. Journal of Dairy Science 87 1012-1014

Lacetera N, Scalia D, Bernabucci U, Ronchi B, Pirazzi D \& Nardone A 2005 Lymphocyte functions in overconditioned cows around parturition. Journal of Dairy Science 88 2010-2016

Lee JS, Pinnamaneni SK, Eo SJ, Cho IH, Pyo JH, Kim CK, Sinclair AJ, Febbraio MA \& Watt MJ 2006 Saturated, but not n-6 polyunsaturated, fatty acids induce insulin resistance: role of intramuscular accumulation of lipid metabolites. Journal of Applied Physiology 1001467 1474

Lessard M, Gagnon N \& Petit HV 2003 Immune response of postpartum dairy cows fed flaxseed. Journal of Dairy Science 86 2647-2657

Lessard M, Gagnon N, Godson DL \& Petit HV 2004 Influence of parturition and diets enriched in $n-3$ or $n-6$ polyunsaturated fatty acids on immune response of dairy cows during the transition period. Journal of Dairy Science 87 2197-2210

Lomax MA \& Baird GD 1983 Blood flow and nutrient exchange across the liver and gut of the dairy cow. Effects of lactation and fasting. British Journal of Nutrition 49 481-496

Mashek DG, Bertics SJ \& Grummer RR 2005 Effects of intravenous triacylglycerol emulsions on hepatic metabolism and blood metabolites in fasted dairy cows. Journal of Dairy Science 88 100-109

National Research Council 2001 Nutrient Requirements of Dairy Cattle. 7th rev. ed. Natl. Acad. Sci., Washington, DC

Pires J, Curi R \& Otton R 2007 Induction of apoptosis in rat lymphocytes by starvation. Clinical Science 112 59-67

SAS user's guide: statistics version 5 edition. Cary, NC: SAS Institute Inc, 2001

Skeaff CM, Hodson L \& McKenzie JE 2006 Dietary-induced changes in fatty acid composition of human plasma, platelet, and erythrocyte lipids follow a similar time course. Journal of Nutrition 136 565-569

Szuster-Ciesielska A, Filar J \& Kandefer-Szerszen M 1995 Depression of interferon production in leukocytes of cows with fat mobilization syndrome. Archivum Immunologiae et Therapiae Experimentalis 43 61-65

Thanasak J, Müller KE, Dieleman SJ, Hoek A, Noordhuizen JPTM \& Rutten VPMG 2005 Effects of polyunsuturated fatty acids on the proliferation of mitogen stimulated bovine peripheral blood mononuclear cells. Veterinary Immunology and Immunopathology 104 289-295

Usui I, Takata Y, Imamura T, Morioka H, Sasaoka T, Sawa T, Ishihara H, Ishiki M \& Kobayashi M 1997 Fatty acid induced insulin resistance in rat-1 fibroblasts overexpressing human insulin receptors: impaired insulin-stimulated mitogen-activated protein kinase activity. Diabetologia 40 894-901

Zurier RB, Rossetti RG, Seiler CM \& Laposata M 1999 Human peripheral blood T lymphocyte proliferation after activation of the T cell receptor: effects of unsaturated fatty acids. Prostaglandins, Leukotrienes and Essential Fatty Acids 60 371-375 